\title{
Progress in Studying Salt Secretion from the Salt Glands in Recretohalophytes: How Do Plants Secrete Salt?
}

\author{
Fang Yuan, Bingying Leng and Baoshan Wang* \\ Key Lab of Plant Stress Research, College of Life Science, Shandong Normal University, Ji'nan, China
}

To survive in a saline environment, halophytes have evolved many strategies to resist salt stress. The salt glands of recretohalophytes are exceptional features for directly secreting salt out of a plant. Knowledge of the pathway(s) of salt secretion in relation to the function of salt glands may help us to change the salt-tolerance of crops and to cultivate the extensive saline lands that are available. Recently, ultrastructural studies of salt glands and the mechanism of salt secretion, particularly the candidate

OPEN ACCESS

Edited by:

Vadim Volkov,

London Metropolitan University, UK

Reviewed by:

Rosario Vera-Estrella,

Universidad Nacional Autónoma

de México, Mexico

Sergey Shabala

University of Tasmania, Australia

Wee Kee Tan,

National University of Singapore,

Singapore

${ }^{*}$ Correspondence:

Baoshan Wang

bswang@sdnu.edu.cn

Specialty section:

This article was submitted to

Plant Physiology,

a section of the journal

Frontiers in Plant Science

Received: 21 October 2015

Accepted: 20 June 2016

Published: 30 June 2016

Citation:

Yuan F, Leng B and Wang B (2016)

Progress in Studying Salt Secretion

from the Salt Glands

in Recretohalophytes: How Do Plants

Secrete Salt? Front. Plant Sci. 7:977.

doi: 10.3389/fp/s.2016.00977 genes involved in salt secretion, have been illustrated in detail. In this review, we summarize current researches on salt gland structure, salt secretion mechanism and candidate genes involved, and provide an overview of the salt secretion pathway and the asymmetric ion transport of the salt gland. A new model recretohalophyte is also proposed.

Keywords: asymmetric ion and water transport, recretohalophyte, salt gland, salt secretion mechanism, salt stress

\section{INTRODUCTION}

Soil salinization has long been known as an environmental problem (Jacobsen and Adams, 1958), and approximately $6 \%$ of the planet's total land, or more than 800 million ha, is affected (Shabala, 2013). Forty-five million ha (20\%) of presently irrigated lands are also saline lands (Munns and Tester, 2008; FAO, 2015; Shelden et al., 2016). In China alone, more than one million acres of agricultural land are salt affected due to irrigation water containing high soluble salts ${ }^{1}$. Moreover, secondary salinization caused by inappropriate irrigation is increasing in many countries, and it is difficult to reclaim land once degraded in this way despite the availability of substantial funding for land recovery. Few crops can survive in salt-affected regions, leading to substantially reduced production and often further degradation and desertification (Flowers and Colmer, 2008). Halophytes are considered promising species for the use and improvement of saline land (Song and Wang, 2014).

Halophytes, which constitute $0.4 \%$ of the total plants in the world, are plants that can survive and complete their life cycle in media containing more than $200 \mathrm{mM} \mathrm{NaCl}$ (Flowers and Colmer, 2008; Santos et al., 2015). Amongst these halophytes there is a small number that are able to secrete salt from their leaves, the so-called recretohalophytes (Flowers et al., 2015). There are approximately 370 recretohalophyte species all over the world according to statistics from

\footnotetext{
${ }^{1}$ http://www.fao.org/home/en/
} 
Breckle (1995), Zhou et al. (2001), Flowers and Colmer (2008), and Flowers et al. (2010). Recretohalophytes are distributed widely around the globe, inhabiting seawater and inland saline lands $\left(\mathrm{eHALOPH}{ }^{2}\right)$. Salt-secreting structures, namely salt bladders (Figure 1A) and salt glands (Figure 1B), are the unique structures that directly secrete these ions out of the plant, and they are also notable for their presence in recretohalophytes and absence from other halophytes and all non-halophytes (Shabala et al., 2014; Yuan et al., 2015).

Salt bladders and salt glands differ in their structure. Salt bladders are composed of one bladder cell, without or with one or more stalk cells while salt glands consist of either two- or multicellular structures (the details are discussed in the section, The Reported Recretohalophytes and the Structural Characteristics of Salt Glands). Single epidermal cells can function as a salt bladder, as seen in Mesembryanthemum crystallinum and bladders are often modified trichomes. Salt bladders once differentiated, expand rapidly and after exposure of the plant to salt may break up releasing ions to the environment. Salt glands form stable structures that directly secrete salt out of the plant to the external environment.

The earliest studies on salt secretion were performed on the salt bladders of Hormosira banksii (Bergquist, 1959) and the salt glands of Spartina townsendii (Skelding and Winterbotham, 1939). Since the latter half of the 20th

${ }^{2}$ http://www.sussex.ac.uk/affiliates/halophytes/ century, more investigations on the ultrastructure and salt secretion of recretohalophytes have been performed. In recent decades, remarkable progress has been made in explaining salt exclusion and secretion mechanisms and the development of salt bladders and salt glands, with most studies concentrating on two plants, Chenopodium quinoa and Limonium bicolor. C. quinoa is a typical recretohalophyte that possesses salt bladders, and its salt secretion mechanism and salt transport pathway were illustrated in detail in a recent review (Shabala et al., 2014). Comparison of metabolic changes in salt-treated relative to control samples without $\mathrm{NaCl}$ treatment showed that 352 different metabolites were identified in bladder cells of M. crystallinum under salt treatment (Barkla and VeraEstrella, 2015). Recent studies of Oh et al. (2015) presented a transcriptomic analysis of bladder cells of $M$. crystallinum demonstrating cell-type-specific responses during adaptation to salt. The latest study of Atriplex canescens showed that the increasing of $\mathrm{Na}^{+}$accumulation in salt bladders can enhance the salt tolerance (Pan et al., 2016). L. bicolor has multicellular salt glands and the mechanisms of development and salt secretion, in particular the candidate genes, have been studied (Feng et al., 2014; Yuan et al., 2015): more detail is provided below.

The topics of salt glands and salt secretion have been previously reviewed and details of publications prior to 2010s can be found in Flowers and Colmer (2008), Ding et al. (2010b), and Flowers et al. (2010, 2015). In the current review, in addition

A
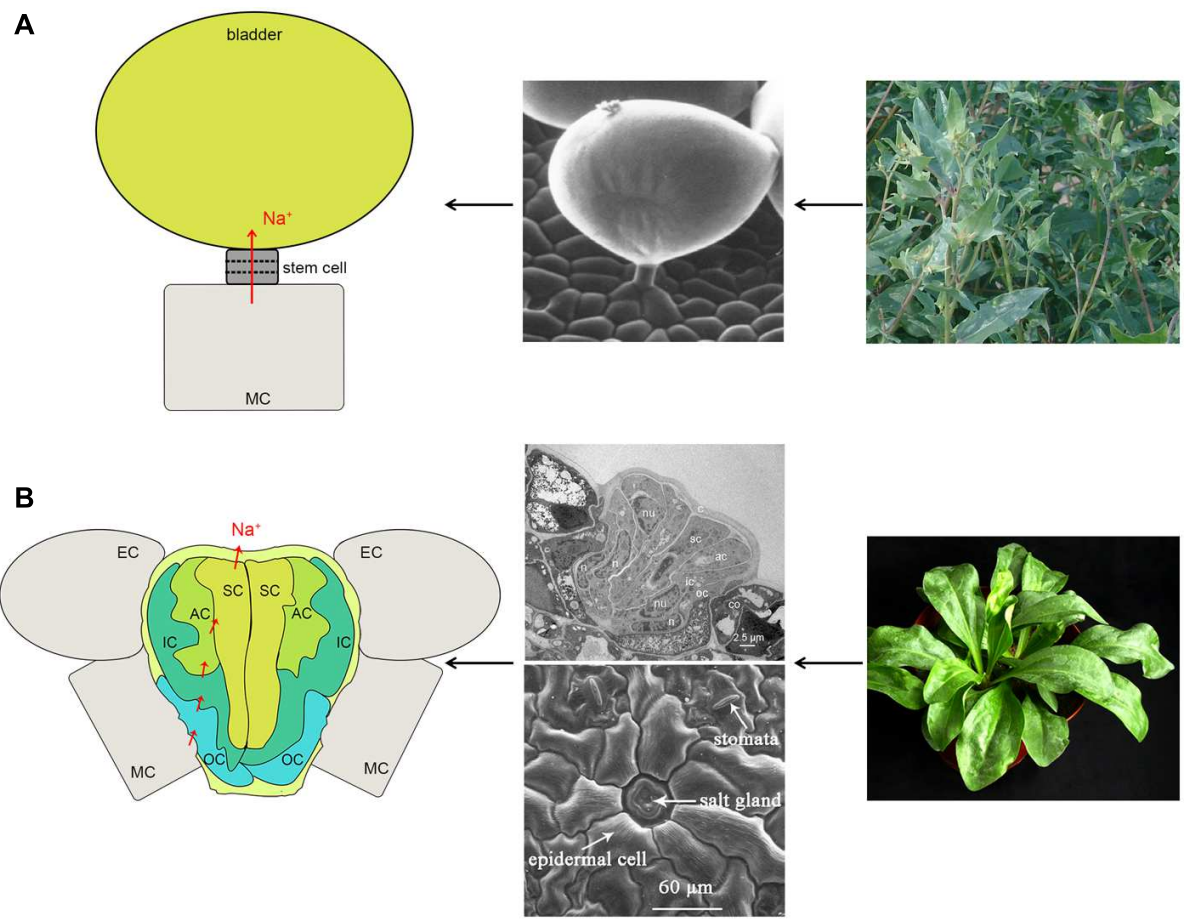

FIGURE 1 | The structure and $\mathrm{Na}^{+}$secretion pathway of a salt bladder (A) and a salt gland (B). (A) The large balloon represents the typical structure of the salt bladder. $\mathrm{Na}^{+}$can be transported into the balloon and released after bladder rupture. The representative plant is Atriplex centralasiatica. (B) The typical multi-cellular salt gland and the $\mathrm{Na}^{+}$pathway. The representative plant is Limonium bicolor. The photographs in (B) are reproduced from Feng et al. (2014) and Yuan et al. (2015) with some modifications. SC, secretory cell; AC, accessory cell; IC, inner cup cell; OC, outer cup cell; MC, mesophyll cell; EC, epidermal cell. 
to the basics before 2010s, we mainly focus on salt secretion mechanisms in salt gland in recretohalophyte that were published in the last 5 years.

\section{THE REPORTED RECRETOHALOPHYTES AND THE STRUCTURAL CHARACTERISTICS OF SALT GLANDS}

To date, the following 11 families (65 species) have been discovered to have salt gland structures (Figure 2): Scrophulariaceae (one species; and the following number in parenthesis after each family represents the number of recretohalophyte species reported in that family), Frankeniaceae (1), Primulaceae (1), Myrsinaceae (2), Acanthaceae (2), Sonneratiaceae (3), Verbenaceae (5), Conovolvulaceae (8), Plumbagenaceae (12), Tamaricaceae (15), and Poaceae (15) according to the statistics of Zhou et al. (2001), Zhao et al. (2002), and Flowers et al. (2010). Most species were reported to have strong salt-secreting abilities as shown in Figure 2, e.g., Frankenia grandifolia of Frankeniaceae (Balsamo and Thomson, 1993), Glaux maritima of Primulaceae
(Rozema and Riphagen, 1977), Aegiceras corniculatum of Myrsinaceae (Ball, 1988; Parida et al., 2004), Acanthus ilicifolius of Acanthaceae (Ye et al., 2005), Sonneratia caseolaris of Sonneratiaceae (Shan et al., 2008), Avicennia marina of Verbenaceae (Ball, 1988; Chen et al., 2010), L. bicolor of Plumbagenaceae (Ding et al., 2010a), and Reaumuria trigyna of Tamaricaceae (Dang et al., 2013). In the Poaceae, most genera showed low salt secretion ability except Aeluropus (Pollak and Waisel, 1970; Barhoumi et al., 2007), Sporobolus (Ramadan, 2001), and Spartina (Bradley and Morris, 1991). Attempts have been made to link the structure of salt gland (Zhao et al., 2002) to the salt secreting ability in two other families (Scrophulariaceae and Conovolvulaceae), and more findings involved in secretion ability will likely be discovered in both families in the near future.

The salt glands in different species possess various structural characteristics. The number of component cells has been used to separate multi-cellular salt gland and bi-cellular salt gland (Figure 1). In general, the salt glands in dicotyledonous recretohalophytes are multi-cellular and sunken into the epidermis. For instance, eight cells were identified in Tamarix

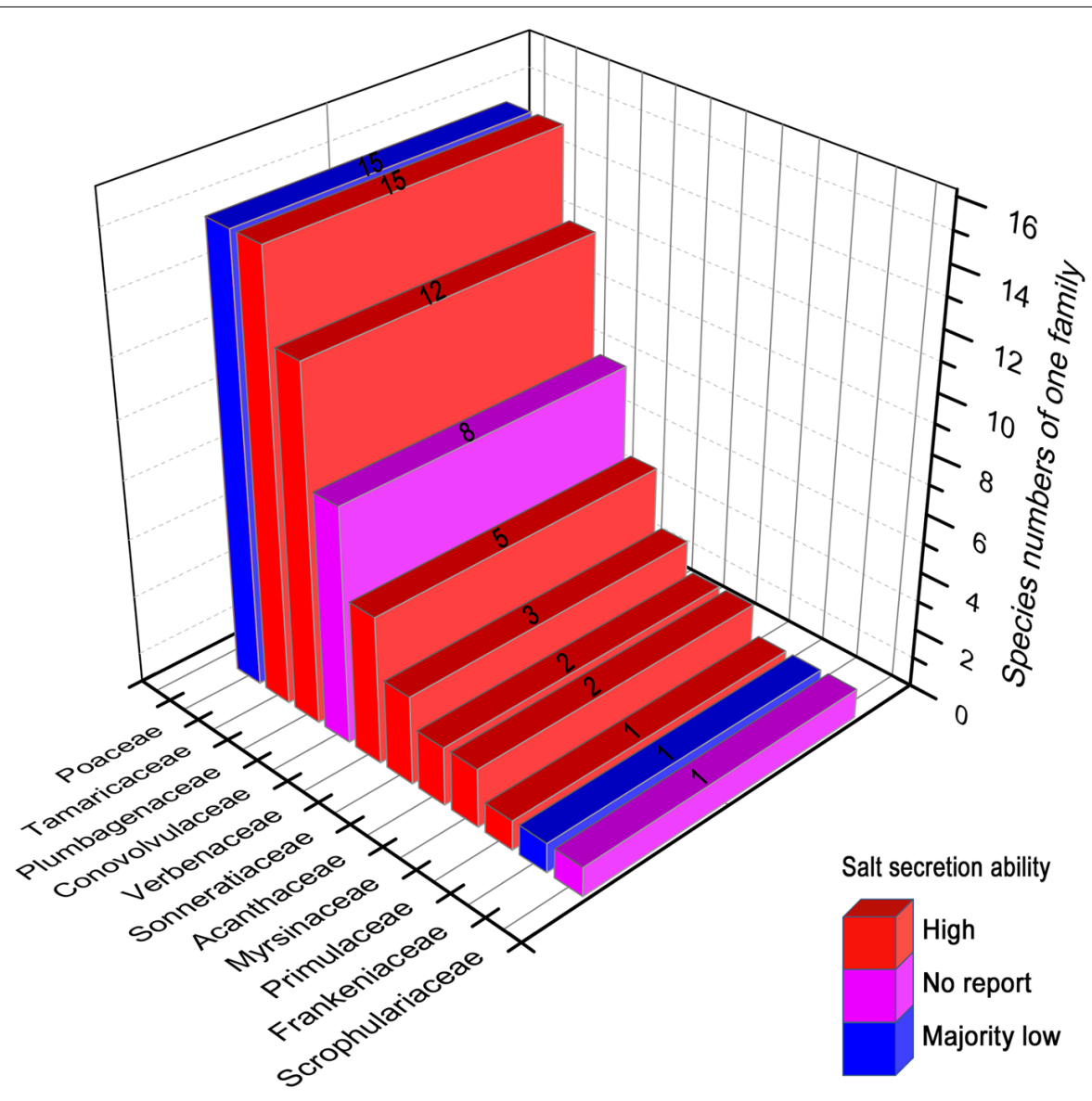

FIGURE 2 | The reported recretohalophytes possessing salt glands with different salt secretion ability. The numbers on the bars presented the species numbers of one family. Red, the species of these families showed strong salt secretion. Purple, there has been no report about the salt secretion in these families until now. Blue, majority of this family showed week salt secretion except Aeluropus, Sporobolus, and Spartina. The figures were drawn with reference to Zhou et al. (2001) and Zhao et al. (2002). 
aphylla with six secreting cells and two collecting cells in a symmetrical structure (Thomson and Platt-Aloia, 1985). Similarly, in L. bicolor, the salt glands consist of 16 cells, with four groups each of outer cup cells, inner cup cells, accessory cells and secretory cells (Figure 1B; Ding et al., 2010a; Feng et al., 2015; Yuan et al., 2015). Species of mangroves (of the Verbenaceae) grow in intertidal zone and possess salt glands with different numbers of secretory cells, e.g., 6-8 secretory cells in A. officinalis (Tan et al., 2010), 8-12 reported in A. marina (Shimony et al., 1973; Drennan et al., 1987), and eight found in Avicennia germinans (Balsamo and Thomson, 1993). In contrast to the multi-cellular glands, bi-cellular salt glands are found in the monocotyledonous recretohalophytes of the Poaceae, in species of Aeluropus, Sporobolus, Spartina, and Zoysia (see Ramadan and Flowers, 2004; Chen et al., 2009; Semenova et al., 2010; Céccoli et al., 2015). In all of the above examples, the innermost cells of the salt glands were positioned adjacent to the mesophyll cells, e.g., the collection cells in Tamarix and the outer cup cells in Limonium.

An interesting feature of salt glands is their autofluorescence under UV excitation (e.g., of L. bicolor; Yuan et al., 2013). By successfully isolating the salt gland complex in vitro, Tan et al. (2010) showed that in A. officinalis this phenomenon was produced by the cuticles around the salt gland and that these complexes are acidic in nature. Recently, Deng et al. (2015) used Sudan IV staining to show that the autofluorescent substance was localized in the cuticle of the salt glands, and simultaneously suggested that the ferulic acid in the cuticle was directly involved in the salt secretion of the L. bicolor salt gland. The cuticle was considered an essential structure for preventing leakage of ions and for protecting the mesophyll from salt damage. The detailed roles of autofluorescencing substances and the cuticle in salt secretion are the subjects of ongoing study.

\section{COMPARISON BETWEEN DIFFERENT METHODS FOR MEASURING SALT SECRETION}

The salt secretion activity of a salt gland can be observed with the naked eye (e.g., Figure 3) or measured using leaf disks (Campbell et al., 1974; Thomson, 1975), a methodology that was recently improved by the use of oil (Yuan et al., 2013). In L. bicolor, in total $5 \mathrm{mg} \mathrm{Na}{ }^{+}$secretion on single mature leaf in $24 \mathrm{~h}$, treated with $92 \mathrm{mg} \mathrm{NaCl}(200 \mathrm{mM})$ each day. By brushing the salt bladders from the surface of leaves in $A$. canescens, the $\mathrm{Na}^{+}$concentration in bladders significantly raised with the increasing of external $\mathrm{NaCl}$ (Pan et al., 2016). However, these methods do not provide direct evidence of salt secretion by a single salt gland, so credible techniques are required in order to determine the salt secretion of a single salt gland. Such methods have been developed over the last 20 years (Table 1). X-ray microanalysis was first applied to Porteresia coarctata (Flowers et al., 1990) and T. aphylla (Storey and Thomson, 1994), and this method showed that the salt gland secreted $\mathrm{Ca}, \mathrm{Mg}$, and $\mathrm{S}$ as well as $\mathrm{Na}$ and $\mathrm{Cl}$. Later, in the saltsecreting mangrove $A$. marina, X-ray fluorescence was used to

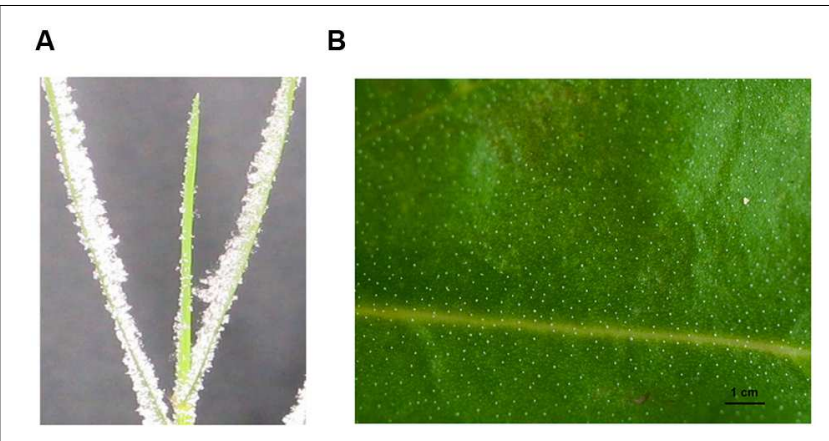

FIGURE 3 | The salt secretion of the salt gland with a distinct salt crystals on the leaves of Distichlis spicata (A) and Limonium bicolor (B). The photograph in (A) was reproduced from Semenova et al. (2010). The leaf blades of $D$. spicata exhibited salt crystals on their leaf surfaces after the plants were incubated in $0.55 \mathrm{mM} \mathrm{NaCl}$ solution for 20-24 h under conditions that prevented the slightest air flow (Semenova et al., 2010). The photograph in (B) was reproduced from Feng et al. (2014). Leaves of L. bicolor that were treated with $200 \mathrm{mM} \mathrm{NaCl}$ displayed distinct salt crystals on the surface of leaves, and the salt secretion rate per single salt gland was $8 \mathrm{ng} \mathrm{h}^{-1}$, which is equivalent to a $5 \mathrm{mg} \mathrm{Na}^{+}$secretion from a single mature leaf within $24 \mathrm{~h}$ after it was treated with $92 \mathrm{mg} \mathrm{NaCl}$ (200 mM) per day.

determine the elemental composition with respect to $\mathrm{Na}, \mathrm{Cl}, \mathrm{K}$, S, Ca, Br, and Zn (Sobrado and Greaves, 2000). SNP (sodium nitroprusside, a NO donor) significantly increased, particularly the $\mathrm{Na}^{+}$-to- $\mathrm{K}^{+}$ratio in the salt glands of $A$. marina as measured by X-ray (Chen et al., 2010). Until recently, X-ray microanalysis was an accurate tool for measuring salt gland secretion and the position of the elements in the salt gland.

Subsequently, methods combining scanning electron microscopy (SEM) with X-ray were rapidly developed to measure salt secretion by single salt gland. Chloris gayana was found to secrete salt through its bicellular salt glands without rupturing the cuticle on the cap cell (Oi et al., 2013). Besides, salt glands can be identified in SEM images of intact leaves of Cynodon dactylon without any need for sectioning (Parthasarathy et al., 2015), and the salt glands observed by SEM in L. bicolor were apparently covered by exudates (Feng et al., 2014), which ensured the accuracy of observation in situ. Subcellular structures of the salt gland were also available by SEM and X-ray: in Limoniastrum guyonianum, where accumulating cells contained numerous, large and unshaped vacuoles (Zouhaier et al., 2015). SEM can also show the real-time secretion status of a salt gland and provide an in-depth understanding of structure-function relationships in multicellular salt glands (Zouhaier et al., 2015). Over a period of time, SEM has been recognized as the most precise and accurate means to observe salt secretion. However, the use of SEM and X-ray microanalysis in the estimation of salt secretion is beset by complicated sample preparation procedures. Consequently, researchers required more accurate and efficient methods in order to measure salt secretion rapidly and precisely.

Over the past 5 years, a new method called Non-invasive Microsensing System (NMS)-BIO-001A (Younger USA Sci.\&Tech) has been widely applied to measure the secretion 
TABLE 1 | Comparative summary for different methods to measure salt secretion in recretohalophyte.

\begin{tabular}{|c|c|c|c|c|c|c|}
\hline Method & Principle of the method & Advantages & Disadvantages & $\begin{array}{l}\text { Secreted ions } \\
\text { and } \\
\text { concentration }\end{array}$ & $\begin{array}{l}\text { Possible } \\
\text { driving } \\
\text { forces }\end{array}$ & $\begin{array}{l}\text { Applications in } \\
\text { recretohalophytes }\end{array}$ \\
\hline $\begin{array}{l}\text { Leaf disks secretion } \\
\text { covered with oil }\end{array}$ & $\begin{array}{l}\text { The method was first developed by } \\
\text { Faraday et al. (1986) and Dschida } \\
\text { et al. (1992), and recently improved } \\
\text { by the use of oil (Yuan et al., 2013). } \\
\text { The secreted ion solution by salt } \\
\text { glands on single leaf can be } \\
\text { isolated in oil droplets. The } \\
\text { accurate ion concentration can be } \\
\text { obtained in the further steps. }\end{array}$ & $\begin{array}{l}\text { Simple method without a } \\
\text { need of special } \\
\text { equipment, and usually } \\
\text { costs } 12-24 \text { h. } \\
\text { Resolution is at the level } \\
\text { of whole plant or the } \\
\text { single leaf. }\end{array}$ & $\begin{array}{l}\text { Cannot provide } \\
\text { direct evidence of } \\
\text { salt secretion by a } \\
\text { single salt gland. }\end{array}$ & $\begin{array}{l}\mathrm{Na}^{+} \\
20-200 \mathrm{mM} \\
\mathrm{K}^{+} 5-20 \mathrm{mM} \\
\mathrm{Mg}^{2+} \\
4-11 \mathrm{mM} \\
\mathrm{Ca}^{2+} \\
0-10 \mathrm{mM}, \mathrm{Cl}^{-} \\
20-200 \mathrm{mM}, \\
\text { et al. }\end{array}$ & $\begin{array}{l}\text { HKT1, } \\
\text { CNGC, } \\
\mathrm{NSCC} \\
\mathrm{H}^{+} / \mathrm{Cl}^{-} \\
\text {symporter }\end{array}$ & $\begin{array}{l}\text { Limonium bicolor } \\
\text { (Faraday et al., } \\
\text { 1986; Yuan et al., } \\
\text { 2013); Avicennia } \\
\text { germinans (Dschida } \\
\text { et al., 1992) }\end{array}$ \\
\hline X-ray microanalysis & $\begin{array}{l}\text { In X-ray analysis, the ratio of } \\
\text { intensity of a target element of } \\
\text { unknown concentration to that of } \\
\text { an internal standard of known } \\
\text { concentration is related to the } \\
\text { concentration of the target element. } \\
\text { The relative elemental sensitivity of } \\
\text { the spectrometer was determined } \\
\text { by the analysis of a multi-elemental } \\
\text { aqueous standard solution } \\
\text { containing V, Co, Zn, Se, and Sr } \\
\text { (Sobrado and Greaves, 2000). }\end{array}$ & $\begin{array}{l}\text { The method allows } \\
\text { determinations in both } \\
\text { materials from plants and } \\
\text { animal species and is a } \\
\text { useful tool because it } \\
\text { provides multi-elemental } \\
\text { analysis simultaneously. }\end{array}$ & $\begin{array}{l}\text { Requires special } \\
\text { equipment and } \\
\text { strict procedure. }\end{array}$ & $\begin{array}{l}\mathrm{Na}^{+} \\
20-200 \mathrm{mM} \\
\mathrm{K}^{+} 5-10 \mathrm{mM} \\
\mathrm{Ca}^{2+} 1-3 \mathrm{mM} \\
\mathrm{Mg}^{2+} 2-6 \mathrm{mM} \\
\mathrm{SO}_{4}^{2-} \\
2-6 \mathrm{mM}, \text { et al. }\end{array}$ & $\begin{array}{l}\text { HKT1, } \\
\text { CNGC, } \\
\text { NSCC }\end{array}$ & $\begin{array}{l}\text { Porteresia } \\
\text { coarctata (Flowers } \\
\text { et al., 1990); } \\
\text { Tamarix aphylla } \\
\text { (Storey and } \\
\text { Thomson, 1994); } \\
\text { Avicennia marina } \\
\text { (Sobrado and } \\
\text { Greaves, 2000; } \\
\text { Chen et al., 2010) }\end{array}$ \\
\hline $\begin{array}{l}\text { Method combined } \\
\text { scanning electron } \\
\text { microscopy (SEM) } \\
\text { with X-ray }\end{array}$ & $\begin{array}{l}\text { The method is based on SEM and } \\
\text { X-ray analysis. SEM can give the } \\
\text { clear component cells of salt glands } \\
\text { and the secreted salts on the salt } \\
\text { gland. In addition, X-ray can } \\
\text { measure the ions by salt secretion } \\
\text { in the specified locations. The } \\
\text { structure-function relationships can } \\
\text { be explored in-deep. }\end{array}$ & $\begin{array}{l}\text { The method can give the } \\
\text { intuitive secreted salt } \\
\text { drops without any need } \\
\text { for sectioning. Besides, } \\
\text { this combined means } \\
\text { may give the real-time } \\
\text { secretion status of a salt } \\
\text { gland. This is the most } \\
\text { precise and accurate } \\
\text { means to observe salt } \\
\text { secretion and measure } \\
\text { secreted ions. }\end{array}$ & $\begin{array}{l}\text { Due to the } \\
\text { complicated } \\
\text { sample preparation } \\
\text { procedures, this } \\
\text { method required } \\
\text { more accurate and } \\
\text { efficient operations } \\
\text { in order to measure } \\
\text { salt secretion } \\
\text { rapidly and } \\
\text { precisely. }\end{array}$ & $\begin{array}{l}\mathrm{Na}^{+} \\
20-200 \mathrm{mM}, \\
\mathrm{K}^{+} 5-20 \mathrm{mM} \text {, } \\
\text { et al. }\end{array}$ & $\begin{array}{l}\text { HKT1, } \\
\text { CNGC }\end{array}$ & $\begin{array}{l}\text { Chloris gayana (Oi } \\
\text { et al., 2013); } \\
\text { Cynodon dactylon } \\
\text { (Parthasarathy } \\
\text { et al., 2015); } \\
\text { Limoniastrum } \\
\text { guyonianum } \\
\text { (Zouhaier et al., } \\
\text { 2015) }\end{array}$ \\
\hline $\begin{array}{l}\text { Non-invasive } \\
\text { Microsensing } \\
\text { System } \\
\text { (NMS)-BIO-001A } \\
\text { (Younger USA } \\
\text { Sci.\&Tech) }\end{array}$ & $\begin{array}{l}\text { The ions can be measured by } \\
\text { moving an electrode repeatedly } \\
\text { between two positions in a } \\
\text { predefined excursion ( } 5-30 \mu \mathrm{m} \text { ) at } \\
\text { a programmable frequency in the } \\
\text { range } 0.01-10.00 \mathrm{~Hz} \text { with a range } \\
\text { of } 0.3-0.5 \mathrm{~Hz} \text { being typical for } \\
\text { many types of electrodes. }\end{array}$ & $\begin{array}{l}\text { The measurement of salt } \\
\text { secretion of single salt } \\
\text { gland is realized by this } \\
\text { method. The salt } \\
\text { secretion can be } \\
\text { detected real-time. Most } \\
\text { of inorganic ions can be } \\
\text { measured, usually } \\
\text { 5-20 min to measure one } \\
\text { ion with simple operation. }\end{array}$ & $\begin{array}{l}\text { NMS detects the } \\
\text { net flux of an ion of } \\
\text { a salt gland rather } \\
\text { than ion efflux. } \\
\text { Most of the organic } \\
\text { acid anions cannot } \\
\text { measure. Salt gland } \\
\text { may be destroyed } \\
\text { during peeling the } \\
\text { epidermis. }\end{array}$ & $\begin{array}{l}\mathrm{Na}^{+} \\
20-200 \mathrm{mM}, \\
\mathrm{K}^{+} 5-20 \mathrm{mM}, \\
\mathrm{Cl}^{-} \\
20-200 \mathrm{mM}, \\
\text { et al. }\end{array}$ & $\begin{array}{l}\mathrm{HKT} 1, \\
\mathrm{H}^{+} / \mathrm{Cl}^{-} \\
\text {symporter }\end{array}$ & $\begin{array}{l}\text { Avicennia marina } \\
\text { (Chen et al., 2010); } \\
\text { Limonium bicolor } \\
\text { (Feng et al., 2014) }\end{array}$ \\
\hline $\begin{array}{l}\text { Nanoscale } \\
\text { secondary ion } \\
\text { mass spectrometry } \\
\text { (SIMS) }\end{array}$ & $\begin{array}{l}\text { This method is operated combined } \\
\text { with high-pressure freezing (HPF) } \\
\text { and freeze substitution (FS). The } \\
\text { bombardment of ions results in the } \\
\text { ejection of charged atomic and } \\
\text { molecular species from the surface } \\
\text { layers of the sample. These } \\
\text { secondary ions are then separated } \\
\text { on the basis of their } \\
\text { mass-to-charge ratio using a } \\
\text { high-performance mass } \\
\text { spectrometer, and are correlated } \\
\text { with their spatial origin to form a } \\
\text { chemical image (Smart et al., 2010). }\end{array}$ & $\begin{array}{l}\text { The ions can be } \\
\text { measured with spatial } \\
\text { resolutions of better than } \\
100 \mathrm{~nm} \text {. The accurate ion } \\
\text { distribution and } \\
\text { concentration are } \\
\text { showed on a chemical } \\
\text { image based on TEM } \\
\text { analysis. This method } \\
\text { resolved the problems of } \\
\text { ion position, distribution } \\
\text { and content in situ. }\end{array}$ & $\begin{array}{l}\text { More applications } \\
\text { need to be } \\
\text { attempted in salt } \\
\text { secretion of salt } \\
\text { glands. The } \\
\text { complicated and } \\
\text { strict operating } \\
\text { procedures may } \\
\text { limit the wide } \\
\text { applications. }\end{array}$ & $\begin{array}{l}\mathrm{Na}^{+} \\
20-200 \mathrm{mM}, \\
\mathrm{K}^{+} 10-300 \mathrm{mM} \\
\text { in nucleus of } \\
\text { salt gland. }\end{array}$ & $\begin{array}{l}\text { HKT1, } \\
\text { CNGC }\end{array}$ & $\begin{array}{l}\text { Limonium bicolor } \\
\text { (Feng et al., 2015) }\end{array}$ \\
\hline
\end{tabular}

The distinction between the methods is partially arbitrary. The contents are partially referred to Volkov (2015). HKT1, high-affinity $K^{+}$transporter 1; CNGC, cyclic nucleotidegated cation channel; NSCC, non-selective cationic channel. 
of salt glands. Using NMS, Chen et al. (2010) found that SNP treatments significantly increased net $\mathrm{Na}^{+}$efflux from the salt glands of A. marina. Additionally, the $\mathrm{Na}^{+}$secretion rate from L. bicolor was obtained by NMS, which was greatly enhanced by $\mathrm{NaCl}$ treatment (Feng et al., 2014). NMS can realize the aim of measuring salt secretion of single salt gland in vivo and continuous measurement. NMS can detect the net flux of an ion of a salt gland. However, researchers have to peel the epidermis of leaves in order to detect the salt secretion of salt gland. Salt gland may be destroyed during peeling.

Recently, a new technology was introduced to determine the ion position in recretohalophytes, and it is known as nanoscale secondary ion mass spectrometry (SIMS) combined with highpressure freezing (HPF) and freeze substitution (FS), which can achieve higher spatial resolution than NMT (Smart et al., 2010). SIMS was first performed in the recretohalophyte L. bicolor, and Feng et al. (2015) showed that $\mathrm{K}^{+}$, which accumulated in both the cytoplasm and nucleus of salt gland cells under salinity, may play an important role in salt secretion, although the exact mechanism is unknown. The using of SIMS resolved the problems of ion position, distribution and content in situ, but complicated and strict operating procedures limited its application.

In conclusion, methods are now available for the elemental analysis of secretions from salt glands. Now, the question arises as to how the ions are transported into the salt gland and the role played by the unique structure of salt glands in the secretory process.

\section{HOW IS SALT TRANSPORTED INTO THE SALT GLAND?}

Ion transport is the essential factor determining salinity tolerance in plants (Volkov, 2015). Salt gland can secrete various ions, and the secreted elements mainly depend on the environment (Kobayashi et al., 2007). Amounts of inorganic elements were reported to be excluded by salt glands in the late 5 years including various kinds cationic elements ( $\mathrm{Na}, \mathrm{K}, \mathrm{Ca}, \mathrm{N}, \mathrm{Mg}, \mathrm{Fe}, \mathrm{Mn}, \mathrm{Si}$, and $\mathrm{Zn}$ ) and anionic elements $(\mathrm{Cl}, \mathrm{O}, \mathrm{Br}, \mathrm{S}, \mathrm{P}$, and $\mathrm{C}$; Sobrado and Greaves, 2000; Semenova et al., 2010; Oi et al., 2013; Feng et al., 2014, 2015; Céccoli et al., 2015; Parthasarathy et al., 2015; Zouhaier et al., 2015), but secretion of $\mathrm{Na}^{+}$and $\mathrm{Cl}^{-}$is higher than that of other ions (Ding et al., 2010b; Ma et al., 2011).

No direct evidence has been obtained to confirm the pathway of salt transport into the salt gland, but a number of possible paths have been suggested. The innermost cells of the salt glands were positioned adjacent to the mesophyll cells, the unique structures of salt glands determined the salt transported into the salt gland. A question then arises as to what caused salt to transfer from mesophyll cells into the salt gland directionally and without influence from the mesophyll cells. Which structure isolates the salt gland from the mesophyll? The cuticles surrounding the salt gland are likely to play this role.

Previous studies on the salt gland ultrastructure in Spartina foliosa (Levering and Thomson, 1971) and T. aphylla (Thomson et al., 1969) demonstrated that cuticles were present around the salt glands, and they formed a thick barrier from the mesophyll and the external environment. New findings of Distichlis spicata showed that these ions were transported into the salt gland through the bottom penetration area that was not covered by the cuticles of the salt gland, and the cuticles can prevent the ions from backflowing into the mesophyll (Semenova et al., 2010). Ions accumulated in the salt gland via the bottom penetration area and plasmodesmata generated fluid pressure due to the presence of the cuticle, and then secreted through salt gland pores. As stated in the former section, ferulic acid in the cuticle was proved to be directly involved in the salt secretion of salt glands (Deng et al., 2015). Therefore, cuticles play a significant role in salt secretion.

The plasmodesmata were considered as another typical feature in the ultrastructure of salt gland (Thomson and PlattAloia, 1985). Apparently, the plasmodesmata were present as a membrane-lined intercellular bridge between the mesophyll cells and the salt gland, which allowed these plant cells to communicate with virtually all the adjoining cells (Sager and Lee, 2014). The plasmodesmata were assumed to play an essential role in ion transport into the salt gland (Faraday et al., 1986). The callose and lipid are the most important composition of plasmodesmata, which are well-illustrated to be necessary for ion transport (Grison et al., 2015). Plasmodesmata showed dynamic structures that can actively and selectively transport very large molecules between cells (Overall and Blackman, 1996). However, the detailed role and mechanism of the plasmodesmata in salt gland ion transport required further verifications.

Of equal importance, large central vacuoles were not present in the salt gland cells; instead, many vesicles were detected (Thomson and Platt-Aloia, 1985; Tan et al., 2010, 2013). In particular, the neighboring mesophyll cells had much larger vacuoles than normal, and the secretory cells of the salt glands adjacent to the mesophyll cells possessed many small vesicles, such as Limonium (Ziegler and Lüttge, 1967; Yuan et al., 2015; Zouhaier et al., 2015). These small vesicles may play an important role in transporting salt into the salt gland.

In addition to the unique structural characteristics, the membrane-bound translocating proteins are likely to be involved in salt secretion. Another significant pathway passed through the ion carriers or channels inside the plasma membrane of the salt glands, which were similar to those in normal cells with possible exception that these transporters mainly distributed asymmetrically in the other side of plasma membranes of salt gland cells adjacent to the collecting chamber (Figure 4), e.g., the potassium transporter (HKT1 and KUP), the inward rectifier potassium channel (KEA), with the CNGC and NSCCs eventually increasing the $\mathrm{Na}^{+}$accumulation in the cytoplasm of the cells (Flowers et al., 1977; Flowers and Colmer, 2008). A low-affinity $\mathrm{K}^{+}$transporter called AlHKT2;1 from the recretohalophyte Aeluropus lagopoides played an important role in $\mathrm{K}^{+}$uptake during salt stress and in maintaining a high $\mathrm{K}^{+} / \mathrm{Na}^{+}$ratio in the cytosol (Sanadhya et al., 2015b). 


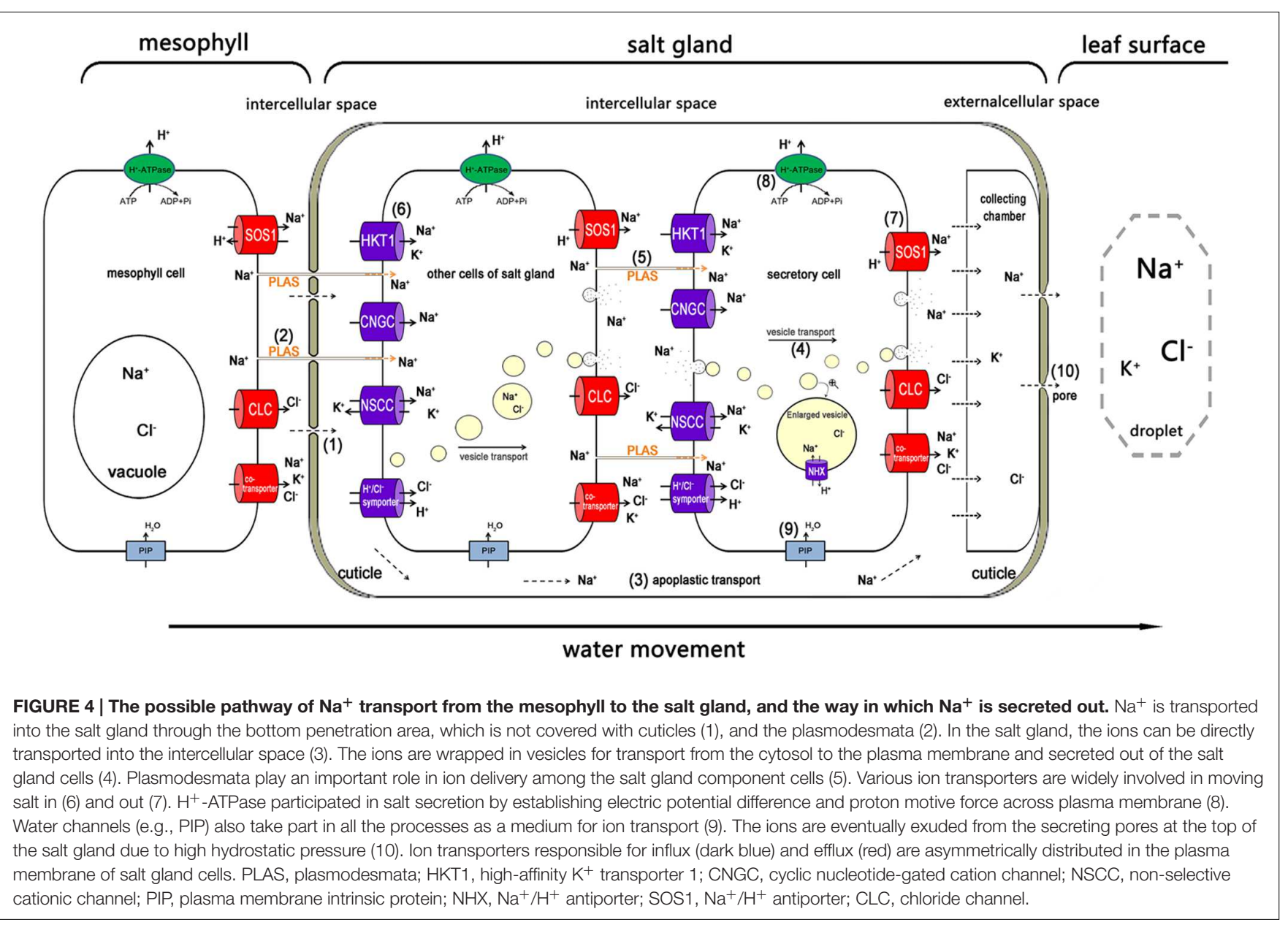

Above all, salt was mainly transported into the salt gland through the plasmodesmata, vesicle transport and ion transporters, which combined with both apoplastic and symplastic transport. Even so, there is still a question as to what mechanism drives the salt out of the salt gland.

\section{A POSSIBLE PATHWAY FOR SECRETING SALT FROM THE SALT GLAND}

As stated above, salt secretion was believed to be an active physiological process of the plant. Various physiological data indicated that salt secretion activity requires large amounts of energy. Salt secretion was typically higher under light treatment than it was in the dark (Dschida et al., 1992). Under salinity, the expression of $\mathrm{H}^{+}$-ATPase in particular increased with the same trend as that of the salt secretion (Chen et al., 2010). However, as reported in T. aphylla and L. bicolor, no chloroplast was present in the salt gland (Thomson and Liu, 1967; Shimony and Fahn, 1968; Yuan et al., 2015). Therefore, the plasmodesmata between the mesophyll cells and the salt glands in L. bicolor may provide the salt gland with photoassimilates and NADPH from the mesophyll cells, which were the original sources of energy for salt excretion. Moreover, during the differentiation of salt glands, mitochondria are the first subcellular organelle differentiated to provide the energy for differentiation of salt gland with small folding mitochondrial crista. The mitochondria in salt glands showed larger scale than that in mesophyll cells (Yuan et al., 2015).

Apparently, all ions are transported out of the salt gland by water; therefore, water efflux is indispensable for salt exclusion. Two aquaporin genes (PIP and TIP) were preferentially expressed in the salt gland cells of $A$. officinalis, and aquaporins were thought to contribute to the re-absorption of water during salt removal (Tan et al., 2013).

Three hypotheses have been proposed to explain the salt secretion of recretohalophytes on the basis of the ultrastructure, and Ding et al. (2010b) have discussed this progress in some detail which rely on (1) the role of the osmotic potential in salt secretion in Limonium latifolium (first suggested by Arisz et al., 1955), (2) a transfer system in S. foliosa that is similar to liquid flow in animals (raised by Levering and Thomson, 1971) and (3) salt solution excretion by vesicles in the plasma membrane (exocytosis; promulgated by Ziegler and Lüttge, 1967; Shimony and Fahn, 1968).

In the current paper, we concentrate on the newest findings on salt secretion that have been uncovered over the last 5 years; interested readers can obtain details of previous results in Ding 
et al. (2010b). The recent findings can be separated into three areas consistent with the previous studies. (1) As far as the first suggestion is concerned, recent finding from a study of D. spicata showed that the parietal layer of the cytoplasm is invaginated into the extracellular space (apoplast), which is separated only by a thin single membrane. A series of vacuolar-apoplastic continua were identified, and they look like a valve (Semenova et al., 2010). Ions are separated in the salt gland by cuticles and then secreted through secreting pores by fluid pressure. (2) Ouabain, a specific $\mathrm{Na}^{+}$-ATPase inhibitor, can inhibit $\mathrm{Na}^{+}$efflux and enhance $\mathrm{K}^{+}$influx by combination with the outside $\mathrm{K}^{+}$ binding sites (Kim et al., 2013; Mette et al., 2015). Comparisons with animal transport systems have shown that in C. gayana (Kobayashi et al., 2007) and the Tamarix species (Ma et al., 2011), salt secretion from their salt glands was significantly decreased in the presence of ouabain, which acts as a salt secretion inhibitor and indicates the existence of liquid flow in salt gland (possible $\mathrm{Na}^{+}$-ATPase). (3) In terms of exocytosis, electrondense substances primarily accumulated in the vesicles of the salt gland in L. bicolor, which showed that under salt treatment, numerous vesicles fused with the plasma membrane (Feng et al., 2014; Yuan et al., 2015). While all three hypotheses have support from studies of different recretohalophytes, in the last few years, more and more evidence has supported the role of exocytosis (Echeverría, 2000). TEM images showed an identifiable vesicletransporting pathway in the salt gland of an L. bicolor leaf that was prepared by HPF, followed by FS and staining (Feng et al., 2015).

Additionally, ion transporters were proposed as another important pathway for salt glands to secrete $\mathrm{Na}^{+} . \mathrm{H}^{+}$ATPase may participate in salt secretion through establishing electrochemical potential difference and proton gradient across plasma membrane of salt gland. Leaf $\mathrm{H}^{+}$-ATPase activity and the photosynthetic capacity of Cakile maritima can enhance salt resistance under increasing salinity (Debez et al., 2006). $\mathrm{H}^{+}$ATPase and the $\mathrm{Na}^{+} / \mathrm{H}^{+}$antiporter are anticipated to have roles in the salt secretion and $\mathrm{Na}^{+}$sequestration of $A$. marina (Chen et al., 2010; Tan et al., 2010). Currently, high-throughput sequencing technology has broad and increasing applications for many recretohalophytes, and it has validated the view that various types of transporters may participate in salt secretion. Transcript profiling in A. lagopoides revealed that HAK, SOS1, and V-ATPase genes play a key role in regulating ion homeostasis (Sanadhya et al., 2015a). NHX and other members of the family play important roles in $\mathrm{K}^{+}$homeostasis, vesicle trafficking and cell expansion (Rodríguez-Rosales et al., 2009). The expression of SOS1 and NHX1 was proportional to the salt secretion in A. marina (Chen et al., 2010).

Recently, the application of transriptomics in recretohalophytes enhances the discovery of candidate genes involved in salt secretion. The transcription profiles of the recretohalophyte $R$. trigyna indicated that the genes related to ion transport were relevant to the salt secretion function of this species (Dang et al., 2013, 2014). Similarly, the candidate genes encoding ion transporters were also suggested in Sporobolus virginicus by RNAseq (Yamamoto et al., 2015). An $\mathrm{NaHCO}_{3}$-treated L. bicolor cDNA library was established (Wang et al., 2008), and a recent
RNA-Seq library containing the different developmental stages of L. bicolor provided an accurate resource for identifying the genes encoding ion carriers and transporters (Yuan et al., 2015).

Nowadays, proteomics was gradually applied to investigate salinity responsive proteins in three recretohalophytes. A celltype-specific proteomics approach was taken in individual epidermal bladder cells of $M$. crystallinum by shotgun peptide sequencing, with a high representation of proteins involved in $\mathrm{H}^{+}$-transport, carbohydrate metabolism, and photosynthesis (Barkla et al., 2012). Besides, Tan et al. (2015a) developed a reliable procedure for obtaining proteins from salt gland-rich tissues of $A$. officinalis and profiled the proteome through 1D-LC-MS/MS. Meanwhile, Tan et al. (2015b) used shotgun proteomics to identify proteins of $A$. officinalis that are present in the salt gland-enriched tissue by comparing the protein profiles of salt gland-enriched (isolated epidermal peels) and salt gland-deprived (mesophyll) tissues, which elucidated the molecular mechanism underlying secretion in plant salt glands. Using the suspension cell cultures of Halogeton glomeratus, iTRAQ-based proteomic approach was conducted to reveal several proteins involved in energy, carbohydrate metabolism, stress defense, protein metabolism, signal transduction, cell growth, and cytoskeleton metabolism (Wang et al., 2016). Transcriptomics combined with proteomics will play an essential role in explaining salt secretion of salt gland of recretohalophytes.

However, all the known transcriptomes and proteomes described above are constructed on the basis of extractions from plant leaves, dominated by mesophyll cells so that genes differentially expressed on salt treatment were very likely derived from mesophyll cells; thus, we cannot determine that these genes are specific to the salt gland unless salt glands are first isolated for sequencing. As mentioned previously, isolating a single salt gland is feasible by enzymolysis in A. officinalis (Tan et al., 2010). Additionally, laser capture microdissection (LCM) technology has been used for separating target cells or tissues in many species (Li et al., 2010). Both methods can be introduced to isolate sufficient amounts of salt glands of sufficient purity for sequencing in the future.

Another approach to understanding salt secretion by recretohalophytes would be to analyze mutants whose salt secretion is in some way modified. Though many mutants in salt secretion have been obtained using gamma ray irradiation (Yuan et al., 2013), no recretohalophyte where specific genes have been silenced has been developed. Until now, the experiments suggesting candidate genes have only been reported in heterologous expression, such as Lbchi32 of L. bicolor verified in pathogenic fungi (Liu et al., 2010). So the mutants in specific and candidate genes should be investigated in the future in order to accurately study molecular mechanism of salt secretion.

\section{CONCLUSION AND PERSPECTIVES}

It is widely accepted that salt secretion is closely aligned with the structure of salt glands (Ding et al., 2010b). Although salt glands 
in different species possess varying characteristics, their common characteristics can be summarized as follows: a thickened cuticle surrounding the salt gland, frequent plasmodesmata, a large number of developed mitochondria, no chloroplasts, and amounts of small vesicles in the cytoplasm (Thomson and PlattAloia, 1985; Ding et al., 2010b; Tan et al., 2013; Yuan et al., 2015). This special structure determines the functionality of bladders and glands; an ion can be rapidly transported from a mesophyll cells into a salt gland and secreted out of the salt gland with a force that is generated by mitochondrial activity and is then transported in vesicles, eventually being excluded through pores (Feng et al., 2014).

Using the muti-cellular salt gland such as L. bicolor as the model, Figure 4 shows the possible pathway for an ion (e.g., $\mathrm{Na}^{+}$) transport from the mesophyll cell into the salt gland and the pathway of ion secretion. Salts from roots are transported upward in the transpiration stream. The salt transport process that moves ions in and out of the salt gland is thought to consist of a combination of both apoplastic and symplastic transport (Flowers and Yeo, 1986; Yeo and Flowers, 1986). Most of the $\mathrm{Na}^{+}$is transported into the salt gland through the basal penetration area that is not covered by cuticles (1), and prevented by the pull of transpiration stream and a valve structure only open inwardly (Semenova et al., 2010), so $\mathrm{Na}^{+}$ cannot reflux through the basal penetration area. In other regions of the salt gland, the cuticles can also prevent ions from penetration into the mesophyll. Another possible pathway of the $\mathrm{Na}^{+}$flowing into the salt gland is the plasmodesmata (2). Once in the salt gland, there are two possible pathways for the movement of $\mathrm{Na}^{+}$. The ions can be directly transported into the intercellular space that is separated from the mesophyll cells by the cuticles (3), where they can be temporarily collected in the collecting chamber. The ions are wrapped in vesicles for transport from the cytosol to the plasma membrane of salt gland cells and for secretion out of the salt gland; the membrane of vesicles can be recycled into plasma membrane. NHX may play an important role in transporting $\mathrm{Na}^{+}$into the vesicles (4). The plasmodesmata provide an important pathway for ion movement between the salt gland component cells (5). Various ion transporters and channels are widely involved in transporting $\mathrm{Na}^{+}$and $\mathrm{Cl}^{-}$in (6) (e.g., HKT1, CNGC, NSCC and $\mathrm{H}^{+} / \mathrm{Cl}^{-}$symporter) and out (7) (e.g., SOS1, CLC and various types of co-transporters) of cells. Ions that are transported by symplastic transport are also temporarily stored in the collecting chamber. During the transport of ions in both import and export pathways, the chemical compounds such as photoassimilate is transported by the plasmodesmata, and ATP is directly generated from highly developed mitochondria (8). Water channels also participate as a medium for ion transport (9). The ions are eventually excluded from the secreting pores that are located in the cuticles in the top of the salt gland due to high hydrostatic pressure (10). The transport of ions from mesophyll cells into and out of salt glands is an asymmetric process, which is a common phenomenon in many biological systems, such as IAA polar transport (Estelle, 1998; Reinhardt et al., 2003), gravity-induced polar transport of calcium across root tips of maize (Lee et al., 1983), iron uptake of the root
(Dubeaux et al., 2015), and etc. The asymmetric distribution of salt secretion components primarily involves the asymmetric ion uptake and efflux; asymmetry in the vesicle transport direction; and asymmetry in ion transporter distribution. Most ions are transported in the direction of the vesicles, and the ion transporters that are responsible for secreting ions out of the salt gland are primarily distributed along the outside of secretory cells.

The study of salt secretion in recretohalophytes has developed considerably in recent years. More evidence has been proposed to explain the salt secretion mechanism; however, uncertainties still exist. On one hand, the salt secretion activity is mediated by multi-cells and multi-genes, and thus, the underlying control of the salt gland development remains unclear. Although, Yuan et al. (2015) have illustrated five differentiation stages in the L. bicolor leaf and proposed that a series of candidate genes can participate in salt gland development and salt secretion (Yuan et al., 2016), the direct validations of the key genes are needed on the basis of these data. On the other hand, RNA-seq has been conducted in five recretohalophytes, but to date, no genome sequencing has been reported in any recretohalophyte. Unclear genetic background made molecular studies difficult, and a new proposed model recretohalophyte is urgently needed. Fortunately, as a typical recretohalophyte possessing salt glands, L. bicolor is a potential model plant for investigating the salt secretion mechanism by salt glands in the future. Partly deficient salt-gland mutants have been obtained by physical and chemical mutagenesis in L. bicolor (Yuan et al., 2013). Moreover, the mutant traits can be kept for long-term investigation because the seeds from these plants can be collected through self-pollination (Yuan et al., 2014b). Based on the established transformation system and leaf disk secretion model (Yuan et al., 2014a), the key genes involved in salt secretion can be transformed for validation. Efficient genome editing in plants using a CRISPR/Cas9 system in non-modal plants will also be used to study molecular mechanism of salt secretion of plant salt gland (Feng et al., 2013). For a decade, various ion transporters have been shown to participate in salt resistance as verified in Arabidopsis and Eutrema/Thellungiella spp. (Lee et al., 2016). However, the in-depth mechanism of halophyte salt tolerance is largely unknown. More and more scientists have begun to use halophytes as materials to study the salt tolerance mechanism. We believe that in the near future, the salt tolerance mechanism will be completely uncovered, and the dream of generating salt-tolerant crops will finally come true.

\section{AUTHOR CONTRIBUTIONS}

FY and BL wrote the manuscript. BW modified the article. All authors read and approved the final manuscript.

\section{FUNDING}

This work has been supported by the NSFC (National Natural Science Research Foundation of China, project No. 31570251), 
Programs Foundation of Ministry of Education of China (20123704130001), Natural Science Research Foundation of Shandong Province (ZR2014CZ002), Young Scientist Research Award Fund of Shandong Province (BS2015SW027), and Technology Plan of Universities of Shandong Province (J15LE08).

\section{REFERENCES}

Arisz, W., Camphuis, I., Heikens, H., and Tooren, A. V. (1955). The secretion of the salt glands of Limonium latifolium Ktze. Acta Bot. Neerl. 4, 322-338. doi: 10.1111/j.1438-8677.1955.tb00334.x

Ball, M. (1988). Salinity tolerance in the mangroves Aegiceras corniculatum and Avicennia marina. I. Water use in relation to growth, carbon partitioning, and salt balance. Funct. Plant Biol. 15, 447-464. doi: 10.1016/j.scitotenv.2013.11.106

Balsamo, R. A., and Thomson, W. W. (1993). Ultrastructural features associated with secretion in the salt glands of Frankenia grandifolia (Frankeniaceae) and Avicennia germinans (Avicenniaceae). Am. J. Bot. 80, 1276-1283. doi: $10.2307 / 2445711$

Barhoumi, Z., Djebali, W., Smaoui, A., Chaïbi, W., and Abdelly, C. (2007). Contribution of $\mathrm{NaCl}$ excretion to salt resistance of Aeluropus littoralis (Willd) Parl. J. Plant Physiol. 164, 842-850. doi: 10.1016/j.jplph.2006.05.008

Barkla, B. J., and Vera-Estrella, R. (2015). Single cell-type comparative metabolomics of epidermal bladder cells from the halophyte Mesembryanthemum crystallinum. Front. Plant Sci. 6:435. doi: 10.3389/fpls. 2015.00435

Barkla, B. J., Vera-Estrella, R., and Pantoja, O. (2012). Protein profiling of epidermal bladder cells from the halophyte Mesembryanthemum crystallinum. Proteomics 12, 2862-2865. doi: 10.1002/pmic.201200152

Bergquist, P. L. (1959). The effect of cations and anions on the respiration rate of the Brown Alga, Hormosira banksii. Physiol. Plant. 12, 30-36. doi: 10.1111/j.1399-3054.1959.tb07882.x

Bradley, P. M., and Morris, J. T. (1991). Relative importance of ion exclusion, secretion and accumulation in Spartina alterniflora Loisel. J. Exp. Bot. 42, 1525-1532. doi: 10.1093/jxb/42.12.1525

Breckle, S. W. (1995). "How do halophytes overcome salinity?" in Biology of Salt Tolerant Plants, eds M. A. Khan and I. A. Ungar (Chelsea: Book Graffers), 199-213.

Campbell, N., Thomson, W. W., and Platt, K. (1974). The apoplastic pathway of transport to salt glands. J. Exp. Bot. 25, 61-69. doi: 10.1007/BF00385168

Céccoli, G., Ramos, J., Pilatti, V., Dellaferrera, I., Tivano, J. C., Taleisnik, E., et al. (2015). Salt glands in the Poaceae family and their relationship to salinity tolerance. Bot. Rev. 81, 162-178. doi: 10.1007/s12229-015-9153-7

Chen, J., Xiao, Q., Wu, F., Dong, X., He, J., Pei, Z., et al. (2010). Nitric oxide enhances salt secretion and $\mathrm{Na}+$ sequestration in a mangrove plant, Avicennia marina, through increasing the expression of $\mathrm{H}+$-ATPase and $\mathrm{Na}+/ \mathrm{H}+$ antiporter under high salinity. Tree Physiol. 30, 1570-1585. doi: 10.1093/treephys/tpq086

Chen, J., Yan, J., Qian, Y., Jiang, Y., Zhang, T., Guo, H., et al. (2009). Growth responses and ion regulation of four warm season turfgrasses to long-term salinity stress. Sci. Hortic. (Amsterdam) 122, 620-625. doi: 10.1016/j.scienta.2009.07.004

Dang, Z. H., Qi, Q., Zhang, H. R., Yu, L. H., Wu, S. B., and Wang, Y. C. (2014). Identification of salt-stress-induced genes from the RNA-Seq data of Reaumuria trigyna using differential-display reverse transcription PCR. Int. J. Genomics 2014:381501. doi: 10.1155/2014/381501

Dang, Z. H., Zheng, L. L., Wang, J., Gao, Z., Wu, S. B., Qi, Z., et al. (2013). Transcriptomic profiling of the salt-stress response in the wild recretohalophyte Reaumuria trigyna. BMC Genomics 14:29. doi: 10.1186/1471-2164-14-29

Debez, A., Saadaoui, D., Ramani, B., Ouerghi, Z., Koyro, H. W., Huchzermeyer, B., et al. (2006). Leaf H+-ATPase activity and photosynthetic capacity of Cakile maritima under increasing salinity. Environ. Exp. Bot. 57, 285-295. doi: 10.1016/j.envexpbot.2005.06.009

Deng, Y., Feng, Z., Yuan, F., Guo, J., Suo, S., and Wang, B. (2015). Identification and functional analysis of the autofluorescent substance in Limonium bicolor salt glands. Plant Physiol. Biochem. 97, 20-27. doi: 10.1016/j.plaphy.2015.09.007

\section{ACKNOWLEDGMENTS}

We are very thankful to Professor Timothy J. Flowers (Department of Evolution, behaviour and environment, School of Life Sciences, University of Sussex) for his constructive suggestions and critical revision of the manuscript.

Ding, F., Chen, M., Sui, N., and Wang, B. S. (2010a). Ca2+ significantly enhanced development and salt-secretion rate of salt glands of Limonium bicolor under $\mathrm{NaCl}$ treatment. S. Afr. J. Bot. 76, 95-101. doi: 10.1016/j.sajb.2009.09.001

Ding, F., Yang, J. C., Yuan, F., and Wang, B. S. (2010b). Progress in mechanism of salt excretion in recretohalopytes. Front. Biol. 5:164-170. doi: 10.1007/s11515010-0032-7

Drennan, P. M., Berjak, P., Lawton, J. R., and Pammenter, N. (1987). Ultrastructure of the salt glands of the mangrove, Avicennia marina (Forssk.) Vierh., as indicated by the use of selective membrane staining. Planta 172, 176-183. doi: 10.1007/BF00394585

Dschida, W., Platt-Aloia, K., and Thomson, W. (1992). Epidermal peels of Avicennia germinans (L.) Stearn: a useful system to study the function of salt glands. Ann. Bot. 70, 501-509.

Dubeaux, G., Zelazny, E., and Vert, G. (2015). Getting to the root of plant iron uptake and cell-cell transport: polarity matters! Commun. Integr. Biol. 8:e1038441. doi: 10.1080/19420889.2015.1038441

Echeverría, E. (2000). Vesicle-mediated solute transport between the vacuole and the plasma membrane. Plant Physiol. 123, 1217-1226. doi: $10.1104 /$ pp.123.4.1217

Estelle, M. (1998). Polar auxin transport: new support for an old model. Plant Cell 10, 1775-1778. doi: 10.2307/3870902

FAO (2015). FAO Land and Plant Nutrition Management Service. Rome: Food and Agriculture Organization of the United Nations.

Faraday, C. D., Quinton, P. M., and Thomson, W. W. (1986). Ion fluxes across the transfusion zone of secreting Limonium salt glands determined from secretion rates, transfusion zone areas and plasmodesmatal frequencies. J. Exp. Bot. 37, 482-494. doi: 10.1093/jxb/37.4.482

Feng, Z., Deng, Y., Zhang, S., Liang, X., Yuan, F., Hao, J., et al. (2015). K+ accumulation in the cytoplasm and nucleus of the salt gland cells of Limonium bicolor accompanies increased rates of salt secretion under $\mathrm{NaCl}$ treatment using NanoSIMS. Plant Sci. 238, 286-296. doi: 10.1016/j.plantsci.2015.06.021

Feng, Z., Sun, Q., Deng, Y., Sun, S., Zhang, J., and Wang, B. (2014). Study on pathway and characteristics of ion secretion of salt glands of Limonium bicolor. Acta Physiol. Plant. 36, 2729-2741. doi: 10.1007/s11738-014-1644-3

Feng, Z., Zhang, B., Ding, W., Liu, X., Yang, D., Wei, P., et al. (2013). Efficient genome editing in plants using a CRISPR/Cas system. Cell Res. 23, 1229-1232. doi: $10.1038 / \mathrm{cr} .2013 .114$

Flowers, T. J., and Colmer, T. D. (2008). Salinity tolerance in halophytes. New Phytol. 179, 945-963. doi: 10.1111/j.1469-8137.2008.02531.x

Flowers, T. J., Flowers, S. A., Hajibagheri, M. A., and Yeo, A. R. (1990). Salt tolerance in the halophytic wild rice, Porteresia coarctata Tateoka. New Phytol. 114, 675-684. doi: 10.1111/j.1469-8137.1990.tb00439.x

Flowers, T. J., Galal, H. K., and Bromham, L. (2010). Evolution of halophytes: multiple origins of salt tolerance in land plants. Funct. Plant Biol. 37, 604-612. doi: 10.1007/s10142-011-0218-3

Flowers, T. J., Munns, R., and Colmer, T. D. (2015). Sodium chloride toxicity and the cellular basis of salt tolerance in halophytes. Ann. Bot. 115, 419-431. doi: 10.1093/aob/mcu217

Flowers, T. J., Troke, P., and Yeo, A. (1977). The mechanism of salt tolerance in halophytes. Annu. Rev. Plant Physiol. 28, 89-121. doi: 10.1146/annurev.pp.28.060177.000513

Flowers, T. J., and Yeo, A. R. (1986). Ion relations of plants under drought and salinity. Funct. Plant Biol. 13, 75-91.

Grison, M. S., Brocard, L., Fouillen, L., Nicolas, W., Wewer, V., Dörmann, P., et al. (2015). Specific membrane lipid composition is important for plasmodesmata function in Arabidopsis. Plant Cell 27, 1228-1250. doi: 10.1105/tpc.114. 135731

Jacobsen, T., and Adams, R. M. (1958). Salt and silt in ancient mesopotamian agriculture. Science 128, 1251-1258. doi: 10.1126/science.128.3334.1251 
Kim, S. H., Yu, H. S., Hong, G. P., Ha, K., Yong, S. K., Shin, S. Y., et al. (2013). Intracerebroventricular administration of ouabain, a Na/K-ATPase inhibitor, activates mTOR signal pathways and protein translation in the rat frontal cortex. Prog. Neuropsychopharmacol. Biol. Psychiatry 45, 73-82. doi: 10.1016/j.pnpbp.2013.04.018

Kobayashi, H., Masaoka, Y., Takahashi, Y., Ide, Y., and Sato, S. (2007). Ability of salt glands in Rhodes grass (Chloris gayana Kunth) to secrete $\mathrm{Na}+$ and $\mathrm{K}+$. Soil Sci. Plant Nutr. 53, 764-771. doi: 10.1111/j.1747-0765.2007.00192.x

Lee, J. S., Mulkey, T. J., and Evans, M. L. (1983). Gravity-induced polar transport of calcium across root tips of maize. Plant Physiol. 73, 874-876. doi: 10.1104/pp.73.4.874

Lee, Y. P., Funk, C., Erban, A., Kopka, J., Köhl, K. I., Zuther, E., et al. (2016). Salt stress responses in a geographically diverse collection of Eutrema/Thellungiella spp. accessions. Funct. Plant Biol. 43, 590-606. doi: 10.1071/FP15285

Levering, C. A., and Thomson, W. W. (1971). The ultrastructure of the salt gland of Spartina foliosa. Planta 97, 183-196. doi: 10.1007/BF00389200

Li, P., Ponnala, L., Gandotra, N., Wang, L., Si, Y., Tausta, S. L., et al. (2010). The developmental dynamics of the maize leaf transcriptome. Nat. Genet. 42, 1060-1067. doi: 10.1038/ng.703

Liu, Z. H., Yang, C. P., Xiao, T. Q., Li, L. X., and Yu, C. W. (2010). Cloning, heterologous expression, and functional characterization of a chitinase gene, lbchi32, from Limonium bicolor. Biochem. Genet. 48, 669-679. doi: 10.1007/s10528-010-9348-x

Ma, H., Tian, C., Feng, G., and Yuan, J. (2011). Ability of multicellular salt glands in Tamarix species to secrete $\mathrm{Na}+$ and $\mathrm{K}+$ selectively. Sci. China Life Sci. 54, 282-289. doi: 10.1007/s11427-011-4145-2

Mette, L., Jonas Lindholt, G., Laure, Y., Poul, N., and Fedosova, N. U. (2015). Structures and characterization of digoxin- and bufalin-bound $\mathrm{Na}+, \mathrm{K}+-$ ATPase compared with the ouabain-bound complex. Proc. Natl. Acad. Sci. U.S.A. 112, 1755-1760. doi: 10.1073/pnas.1422997112

Munns, R., and Tester, M. (2008). Mechanisms of salinity tolerance. Annu. Rev. Plant Biol. 59, 651-681. doi: 10.1146/annurev.arplant.59.032607.092911

Oh, D., Barkla, B., Vera-Estrella, R., Pantoja, O., Lee, S., Bohnert, H., et al. (2015). Cell type-specific responses to salinity-the epidermal bladder cell transcriptome of Mesembryanthemum crystallinum. New Phytol. 207, 627-644. doi: $10.1111 /$ nph.13414

Oi, T., Hirunagi, K., Taniguchi, M., and Miyake, H. (2013). Salt excretion from the salt glands in Rhodes grass (Chloris gayana Kunth) as evidenced by low-vacuum scanning electron microscopy. Flora 208, 52-57. doi: 10.1016/j.flora.2012.12.006

Overall, R. L., and Blackman, L. M. (1996). A model of the macromolecular structure of plasmodesmata. Trends Plant Sci. 1, 307-311. doi: 10.1016/S13601385(96)88177-0

Pan, Y., Guo, H., Wang, S., Zhao, B., Zhang, J., Ma, Q., et al. (2016). The photosynthesis, $\mathrm{Na}+/ \mathrm{K}+$ homeostasis and osmotic adjustment of Atriplex canescens in response to salinity. Front. Plant Sci. 7:848. doi: 10.3389/fpls.2016.00848

Parida, A. K., Das, A. B., Sanada, Y., and Mohanty, P. (2004). Effects of salinity on biochemical components of the mangrove, Aegiceras corniculatum. Aquat. Bot. 80, 77-87. doi: 10.1016/j.aquabot.2004.07.005

Parthasarathy, M., Pemaiah, B., Natesan, R., Padmavathy, S. R., and Pachiappan, J. (2015). Real-time mapping of salt glands on the leaf surface of Cynodon dactylon L. using scanning electrochemical microscopy. Bioelectrochemistry 101, 159-164. doi: 10.1016/j.bioelechem.2014.10.004

Pollak, G., and Waisel, Y. (1970). Salt Secretion in Aeluropus litoralis (Willd.) Parl. Ann. Bot. 34, 879-888.

Ramadan, T. (2001). Dynamics of salt secretion by Sporobolus spicatus (Vahl) Kunth from sites of differing salinity. Ann. Bot. 87, 259-266. doi: 10.1006/anbo.2001.1326

Ramadan, T., and Flowers, T. J. (2004). Effects of salinity and benzyl adenine on development and function of microhairs of Zea mays L. Planta 219, 639-648. doi: 10.1007/s00425-004-1269-7

Reinhardt, D., Pesce, E. R., Stieger, P., Mandel, T., Baltensperger, K., Bennett, M., et al. (2003). Regulation of phyllotaxis by polar auxin transport. Nature 426, 255-260. doi: 10.1038/nature02081

Rodríguez-Rosales, M. P., Gálvez, F. J., Huertas, R., Aranda, M. N., Baghour, M., Cagnac, O., et al. (2009). Plant NHX cation/proton antiporters. Plant Signal. Behav. 4, 265-276. doi: 10.4161/psb.4.4.7919
Rozema, J., and Riphagen, I. (1977). Physiology and ecologic relevance of salt secretion by the salt gland of Glaux maritima L. Oecologia 29, 349-357. doi: 10.1007/BF00345808

Sager, R., and Lee, J. Y. (2014). Plasmodesmata in integrated cell signalling: insights from development and environmental signals and stresses. J. Exp. Bot. 65, 6337-6358. doi: 10.1093/jxb/eru365

Sanadhya, P., Agarwal, P., and Agarwal, P. K. (2015a). Ion homeostasis in a salt-secreting halophytic grass. AoB Plants 7:lv055. doi: 10.1093/aobpla/ plv055

Sanadhya, P., Agarwal, P., Khedia, J., and Agarwal, P. K. (2015b). A low-affinity $\mathrm{K}+$ transporter AlHKT2; 1 from recretohalophyte Aeluropus lagopoides confers salt tolerance in Yeast. Mol. Biotechnol. 57, 489-498. doi: 10.1007/s12033-0159842-9

Santos, J., Al-Azzawi, M., Aronson, J., and Flowers, T. J. (2015). eHALOPH a database of salt-tolerant plants: helping put halophytes to work. Plant Cell Physiol. 57:e10. doi: 10.1093/pcp/pcv155

Semenova, G. A., Fomina, I. R., and Biel, K. Y. (2010). Structural features of the salt glands of the leaf of Distichlis spicata 'Yensen 4a' (Poaceae). Protoplasma 240, 75-82. doi: 10.1007/s00709-009-0092-1

Shabala, S. (2013). Learning from halophytes: physiological basis and strategies to improve abiotic stress tolerance in crops. Ann. Bot. 112, 1209-1221. doi: 10.1093/aob/mct205

Shabala, S., Bose, J., and Hedrich, R. (2014). Salt bladders: do they matter? Trends Plant Sci. 19, 687-691. doi: 10.1016/j.tplants.2014.09.001

Shan, L., Zhou, R. C., Dong, S. S., and Shi, S. H. (2008). Adaptation to salinity in mangroves: implication on the evolution of salt-tolerance. Chin. Sci. Bull. 11, 1708-1715.

Shelden, M. C., Dias, D. A., Jayasinghe, N. S., Bacic, A., and Roessner, U. (2016). Root spatial metabolite profiling of two genotypes of barley (Hordeum vulgare L.) reveals differences in response to short-term salt stress. J. Exp. Bot. 67, 3731-3745. doi: 10.1093/jxb/erw059

Shimony, C., and Fahn, A. (1968). Light and electron microscopical studies on the structure of salt glands of Tamarix aphylla L. J. Linn. Soc. Lond. Bot. 60, 283-288. doi: 10.1111/j.1095-8339.1968.tb00090.x

Shimony, C., Fahn, A., and Reinhold, L. (1973). Ultrastructure and ion gradients in the salt glands of Avicennia marina (Forssk.) Vierh. New Phytol. 72, 27-36. doi: 10.1111/j.1469-8137.1973.tb02006.x

Skelding, A., and Winterbotham, J. (1939). The structure and development of the hydathodes of Spartina townsendii Groves. New Phytol. 38, 69-79. doi: 10.1111/j.1469-8137.1939.tb07085.x

Smart, K. E., Smith, J. A. C., Kilburn, M. R., Martin, B. G., Hawes, C., and Grovenor, C. R. (2010). High-resolution elemental localization in vacuolate plant cells by nanoscale secondary ion mass spectrometry. Plant J. 63, 870-879. doi: 10.1111/j.1365-313X.2010.04279.x

Sobrado, M. A., and Greaves, E. D. (2000). Leaf secretion composition of the mangrove species Avicennia germinans (L.) in relation to salinity: a case study by using total-reflection X-ray fluorescence analysis. Plant Sci. 159, 1-5. doi: 10.1016/S0168-9452(00)00292-2

Song, J., and Wang, B. (2014). Using euhalophytes to understand salt tolerance and to develop saline agriculture: Suaeda salsa as a promising model. Ann. Bot. 115, 541-553. doi: 10.1093/aob/mcu194

Storey, R., and Thomson, W. W. (1994). An X-ray microanalysis study of the salt glands and intracellular calcium crystals of Tamarix. Ann. Bot. 73, 307-313. doi: 10.1006/anbo.1994.1036

Tan, W. K., Ang, Y., Lim, T. K., Lim, T. M., Kumar, P., Loh, C. S., et al. (2015a). Proteome profile of salt gland-rich epidermis extracted from a salt-tolerant tree species. Electrophoresis 36, 2473-2481. doi: 10.1002/elps.201500023

Tan, W. K., Lim, T. M., and Loh, C. S. (2010). A simple, rapid method to isolate salt glands for three-dimensional visualization, fluorescence imaging and cytological studies. Plant Methods 6:24. doi: 10.1186/1746-4811-6-24

Tan, W. K., Lim, T. K., Loh, C. S., Kumar, P., and Lin, Q. (2015b). Proteomic characterisation of the salt gland-enriched tissues of the mangrove tree species Avicennia officinalis. PLOS ONE 10:e0133386. doi: 10.1371/journal.pone.0133386

Tan, W. K., Lin, Q., Lim, T. M., Kumar, P., and Loh, C. S. (2013). Dynamic secretion changes in the salt glands of the mangrove tree species Avicennia officinalis in response to a changing saline environment. Plant Cell Environ. 36, 1410-1422. doi: 10.1111/pce.12068 
Thomson, W., Berry, W., and Liu, L. (1969). Localization and secretion of salt by the salt glands of Tamarix aphylla. Proc. Natl. Acad. Sci. U.S.A. 63, 310-317. doi: 10.1073/pnas.63.2.310

Thomson, W., and Platt-Aloia, K. (1985). The ultrastructure of the plasmodesmata of the salt glands of Tamarix as revealed by transmission and freeze-fracture electron microscopy. Protoplasma 125, 13-23. doi: 10.1007/BF01297346

Thomson, W. W. (1975). "The structure and function of salt glands," in Plants in Saline Environments, Vol. 15, eds A. Poljakoff-Mayber and J. Gale (Heidelberg: Springer), 118-146.

Thomson, W. W., and Liu, L. L. (1967). Ultrastructural features of the salt gland of Tamarix aphylla L. Planta 73, 201-220. doi: 10.1007/BF00387033

Volkov, V. (2015). Salinity tolerance in plants. Quantitative approach to ion transport starting from halophytes and stepping to genetic and protein engineering for manipulating ion fluxes. Front. Plant Sci. 6:873. doi: 10.3389/fpls.2015.00873

Wang, J., Yao, L., Li, B., Meng, Y., Ma, X., Lai, Y., et al. (2016). Comparative proteomic analysis of cultured suspension cells of the halophyte Halogeton glomeratus by iTRAQ provides insights into response mechanisms to salt stress. Front. Plant Sci. 7:110. doi: 10.3389/fpls.2016.00110

Wang, Y., Ma, H., Liu, G., Xu, C., Zhang, D., and Ban, Q. (2008). Analysis of gene expression profile of Limonium bicolor under NaHCO3 stress using cDNA microarray. Plant Mol. Biol. Rep. 26, 241-254. doi: 10.1007/s11105-008-0037-4

Yamamoto, N., Takano, T., Tanaka, K., Ishige, T., Terashima, S., Endo, C., et al. (2015). Comprehensive analysis of transcriptome response to salinity stress in the halophytic turf grass Sporobolus virginicus. Front. Plant Sci. 6:241. doi: 10.3389/fpls.2015.00241

Ye, Y., Tam, N. F.-Y., Lu, C. Y., and Wong, Y. S. (2005). Effects of salinity on germination, seedling growth and physiology of three salt-secreting mangrove species. Aquat. Bot. 83, 193-205. doi: 10.1016/j.aquabot.2005.06.006

Yeo, A. R., and Flowers, T. J. (1986). Ion transport in Suaeda maritima: its relation to growth and implications for the pathway of radial transport of ions across the root. J. Exp. Bot. 37, 143-159. doi: 10.1093/jxb/37.2.143

Yuan, F., Chen, M., Leng, B. Y., and Wang, B. (2013). An efficient autofluorescence method for screening Limonium bicolor mutants for abnormal salt gland density and salt secretion. S. Afr. J. Bot. 88, 110-117. doi: 10.1016/j.sajb.2013.06.007
Yuan, F., Chen, M., Yang, J. C., Leng, B. Y., and Wang, B. S. (2014a). A system for the transformation and regeneration of the recretohalophyte Limonium bicolor. In Vitro Cell. Dev. Biol. Plant 50, 610-617. doi: 10.1007/s11627-0149611-7

Yuan, F., Deng, Y. Q., and Wang, B. S. (2014b). The observation of pollen viability and pollen tube germination in Limonium bicolor. WIT Trans. Biomed. Health 18, 631-636. doi: 10.2495/HHME130841

Yuan, F., Lyu, M. J. A., Leng, B. Y., Zhu, X. G., and Wang, B. S. (2016). The transcriptome of NaCl-treated Limonium bicolor leaves reveals the genes controlling salt secretion of salt gland. Plant Mol. Biol. 91, 241-256. doi: 10.1007/s11103-016-0460-0

Yuan, F., Lyv, M. J., Leng, B. Y., Zheng, G. Y., Feng, Z. T., Li, P. H., et al. (2015). Comparative transcriptome analysis of developmental stages of the Limonium bicolor leaf generates insights into salt gland differentiation. Plant Cell Environ. 38, 1637-1657. doi: 10.1111/pce.12514

Zhao, K. F., Fan, H., and Ungar, I. (2002). Survey of halophyte species in China. Plant Sci. 163, 491-498. doi: 10.1186/1756-0500-7-927

Zhou, S., Han, J. L., and Zhao, K. F. (2001). Advance of study on recretohalophytes. Chin. J. Appl. Environ. Biol. 7, 496-501.

Ziegler, H., and Lüttge, U. (1967). Die Salzdrüsen von Limonium vulgare. Planta 74, 1-17. doi: 10.1007/BF00385168

Zouhaier, B., Abdallah, A., Najla, T., Wahbi, D., Wided, C., Aouatef, B. A., et al. (2015). Scanning and transmission electron microscopy and X-ray analysisof leaf salt glands of Limoniastrum guyonianum Boiss. under $\mathrm{NaCl}$ salinity. Micron 78, 1-9. doi: 10.1016/j.micron.2015.06.001

Conflict of Interest Statement: The authors declare that the research was conducted in the absence of any commercial or financial relationships that could be construed as a potential conflict of interest.

Copyright (c) 2016 Yuan, Leng and Wang. This is an open-access article distributed under the terms of the Creative Commons Attribution License (CC BY). The use, distribution or reproduction in other forums is permitted, provided the original author(s) or licensor are credited and that the original publication in this journal is cited, in accordance with accepted academic practice. No use, distribution or reproduction is permitted which does not comply with these terms. 